\title{
Bewegen bij chronische aandoeningen
}

Anne van Vegchel, sportarts bij het Bravis ziekenhuis

\section{Samenvatting}

Er komt steeds meer kennis over het belang van bewegen en fitheid bij de totale populatie en patiënten met een chronische aandoening in het bijzonder. Toegenomen fitheid zorgt voor primaire en secundaire preventie bij onder andere cardiovasculaire aandoeningen. De tijd dat je met een chronische aandoening beter in bed kon blijven liggen, is gelukkig voorbij. Maar hoe adviseren en motiveren we deze mensen. Overdaad schaadt, maar bij wie kunnen we aankloppen om deze groepen patiënten te begeleiden en te adviseren? Daarvoor is kennis nodig over bewegen en de aandoening zelf. In de meeste regio's zijn er gespecialiseerde fysiotherapeuten of sportartsen om deze categorie mensen te ondersteunen en begeleiden.

\section{Inleiding}

Met de uitbraak van het COVID-19-virus en de overbelasting op de ic's en in de ziekenhuizen, weten we zo langzamerhand dat vooral de chronisch zieken (cardiaal, metabool en pulmonaal) een hoger risico hebben op een gecompliceerd (en fataal) beloop, maar ook de obese (waarschijnlijk de zogenaamde niet fitte) medemens lijkt vaker een ziekenhuisopname te verduren te krijgen dan de fitte medemens. Hoogste tijd om daar wat aan te doen en ook de chronisch zieke in beweging te krijgen. Immers, er is geen medicijn zo goedkoop als een beweegkuur en tegelijkertijd is er geen richtlijn zo lastig te implementeren als een gedragsverandering. Hoewel er veel onderzoeken gedaan zijn naar het falen van deze implementatie op populatieniveau zijn er waarschijnlijk te veel (complexe) problemen die een simpele oplossing in de weg staan.

Waarschijnlijk zal het ook voor een deel aan de terminologie liggen. Zeg tegen een wat obese patiënt met diabetes mellitus type 2 en hypertensie dat hij moet gaan sporten en hij schiet in de verdediging. Mogelijk ervaart deze persoon hetzelfde als wanneer je een gezonde persoon vraagt om over 4 weken de marathon te gaan lopen. Uitleggen wat de voordelen zijn en kleine stapjes zetten (meer in beweging komen), zal een beter effect hebben en als mensen succes ervaren (minder snel buiten adem, zich fitter voelen, minder medicijnen gebruiken) zal dit bijdragen 
aan gedragsverandering. Dat betekent ook dat je er met één consult met adviezen over bewegen niet bent.

Hier kan een rol liggen voor een praktijkondersteuner, maar de patiënt kijkt ook naar de dokter. Als de arts iedere dag met de auto (met alle goede bedoelingen vanwege spoedconsulten en dergelijke) naar het werk komt en gaat, zal dat gesprek over bewegen minder effect sorteren dan wanneer er tussendoor ook zichtbaar bewogen wordt. Denk aan lunchwandelingen of wel eens aan een hoog-laagbureau gedacht waaraan er staand consulten gevoerd kunnen worden? Het is misschien even wennen, maar als we van onze patiënten vragen om minder te zitten en meer in beweging te komen, dan zouden we daarin zelf het voorbeeld moeten zijn.

\section{Motivatie}

Maar hoe motiveer je je patiënt met een chronische aandoening en wat zijn de te verwachten gezondheidseffecten? Over de gezondheidseffecten zijn al veel onderzoeken gedaan. In eerste instantie bij cardiovasculaire ziekten en diabetes ${ }^{2}$, later ook bij parkinson, oncologie en reumatologische aandoeningen. Uit alle onderzoeken blijkt: bewegen helpt in de primaire en secundaire preventie. Daarnaast was er soms (hypertensie en diabetes mellitus) minder medicatie nodig.

Maar hoe adviseer je dan? Allereerst is het van belang een idee te krijgen van wat iemand de gehele dag door doet. Werkt iemand en zo ja, wat voor werk doet hij of zij. Waar werkt iemand, zijn er mogelijkheden om naar het werk te fietsen of om tijdens de lunch te bewegen. Wat doet iemand buiten het werk om en in het weekend? Door daar een beeld van te krijgen, kan er geleidelijk aan een verandering aangebracht worden, nogmaals iemand met een zittend beroep vertellen dat hij of zij twee keer per week naar de sportschool moet om te bewegen kan effectief zijn, maar levert meestal geen echte gedragsverandering op, maar ieder uur opstaan (een rondje lopen), staand bellen en een lunchwandeling maken, leidt al tot het voldoen aan de beweegnorm van 150 minuten per week.

Laat staan wanneer de mogelijkheid benut wordt en er naar het werk gefietst wordt dan wel er in het weekend gewandeld en/of gefietst wordt. Het voldoen aan de beweegnorm kan vervolgens uitgebreid worden naar het voldoen aan de fitnorm (beweegnorm en 3 dagen per week minimaal 20 minuten zwaar intensief bewegen). Let wel: wat voor de een zwaar intensief is (hardlopen op $10-12 \mathrm{~km} /$ uur) is voor een chronisch zieke een heel andere belasting! Dit vraagt dus om meer kennis en daarmee mogelijk een verwijzing.

\section{Hulp bij bewegen}

In de meeste regio's zijn er inmiddels gespecialiseerde fysiotherapiepraktijken die ondersteunen in bewegen voor chronisch zieken. Zij zijn bekend met de ziekte, comorbiditeiten en hebben (enige) kennis van bewegen. Dit is van belang omdat het bewegen wel veilig moet gebeuren. Er zal dan ook altijd een intake plaatsvinden en in geval van 'rode vlaggen' zal er eerst terug verwezen worden naar de huisarts voor eventueel medicatieaanpassing dan wel voor verder onderzoek. 
Doel is hierbij de patiënten vertrouwd te maken met bewegen op een veilige manier. Dat kan door groepslessen, maar individueel begeleiden is ook vaak mogelijk. Daarnaast zal er gekeken worden naar het inpassen van bewegen en sport in het dagelijks leven, liefst in een vorm die aansluit bij de wensen en mogelijkheden van de patiënt.

Soms lukt het echter niet om ondanks alle goede voornemens en trainingen, iemand fitter te laten worden, of vanwege alle comorbiditeiten durft een eerstelijns fysiotherapeut het niet aan. Dan is er de mogelijkheid om iemand door te verwijzen naar de sportarts. Zoals al in het stuk over de sportkeuring genoemd, heeft de sportarts de mogelijkheid om een inspanningstest met ademgas analyse te doen ( $\mathrm{VO}_{2}$ max test) om zo te beoordelen welke schakel (spier-hart-longen) de zwakste is in de beweegketen om zo specifiek hierop te focussen en de trai-

Figuur 1: training, compensatie en supercompensatie

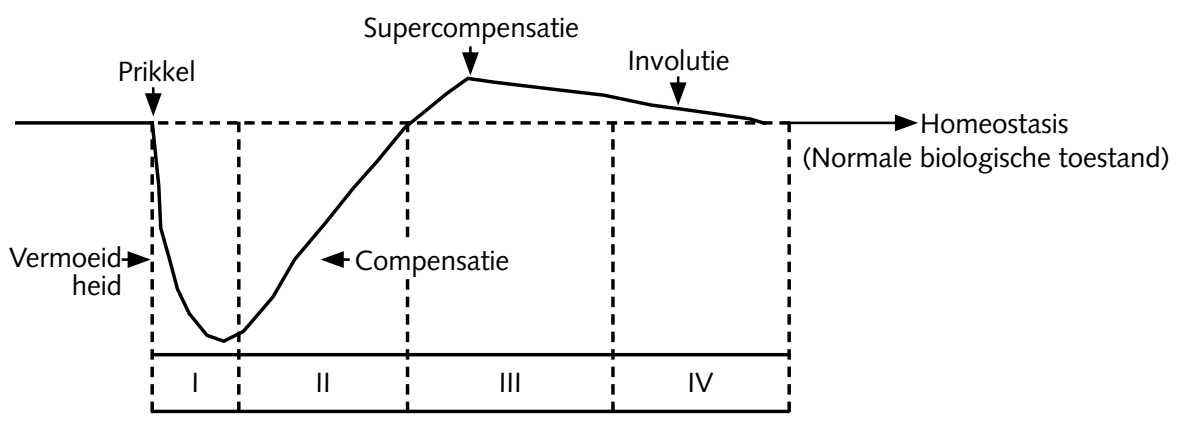

ning er op aan te laten passen. Daarnaast kunnen er adviezen gegeven worden in het kader van belasting en belastbaarheid, want bewegen is goed (noodzakelijk) maar rust is minstens zo belangrijk. In figuur 1. staat het trainingsprincipe van de supercompensatie uitgelegd.

Als we vanuit een beginpunt een trainingsprikkel toepassen, zal er gedurende deze prikkel vermoeidheid ontstaan (fase I). De overgang van fase I naar fase II is het beëindigen van de trainingsprikkel. In fase II treedt er compensatie op: door uit te rusten bereikt de sporter of patiënt weer het uitgangsniveau van voor de training. Fase III is waar we het voor doen: de supercompensatie oftewel conditieopbouw. Helaas duurt de supercompensatie niet eeuwig en als er geen volgende trainingsprikkel komt, zakt het niveau weer terug naar het uitgangsniveau. Idealiter vindt er in fase III een nieuwe trainingsprikkel plaats en bouwt zich conditie op. Komt de training echter te vroeg (in fase II), dan kan er zelfs achteruitgang van conditie optreden terwijl er wel gesport wordt (figuur 2). 
Figuur 2: uit huisarts en wetenschap 2015: conditieopbouw (groene lijn) en te vroeg geplaatst training waardoor achteruitgang (rode lijn)

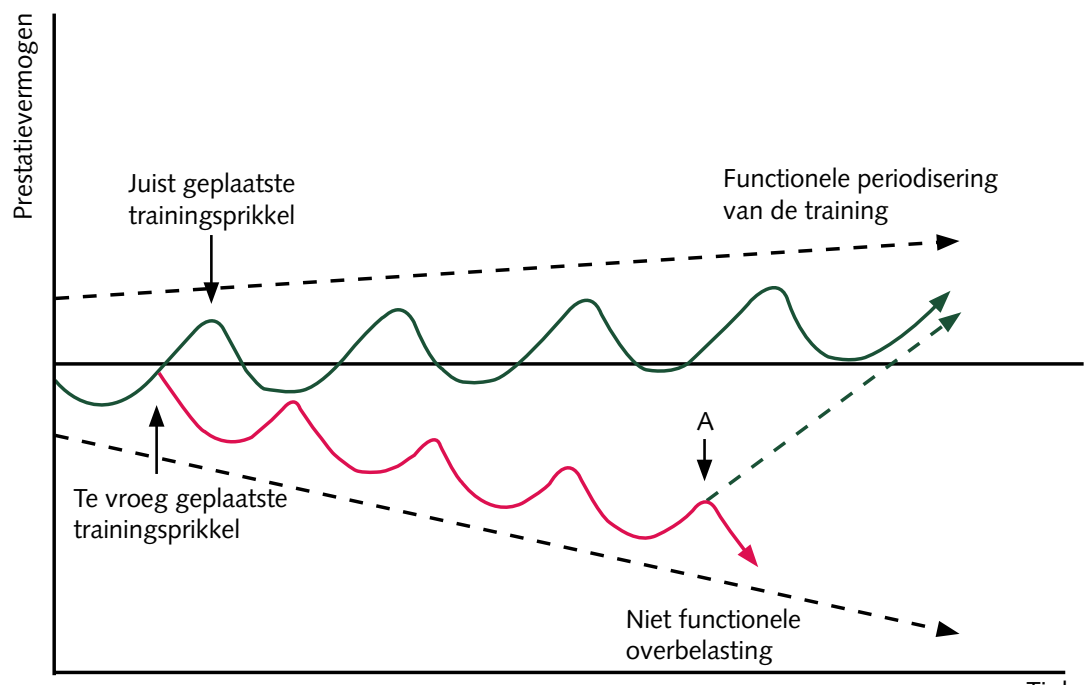

Het bepalen wanneer het juiste moment is om een volgende training uit te voeren is erg lastig omdat dit afhangt van meerdere factoren. Zo bepaalt de zwaarte van de training hoeveel hersteltijd er nodig is (een intervaltraining heeft meer hersteltijd nodig dan een rustige duurtraining), de leeftijd van de sporter is van invloed, andere activiteiten zoals werk, maar zeker ook onderliggende ziektes. Het is dan ook noodzakelijk dat de begeleider van deze patiënt of sporter iets van trainingsleer afweet om overbelasting te voorkomen.

Kortom: bewegen is goed, noodzakelijk zelfs, maar kennis over bewegen en herstel is onontbeerlijk als we de patiënten met een chronische ziekte op de lange termijn aan het bewegen willen houden.

\section{Referenties}

1. Pratt M, Varela AR, Salvo D, Kohl HW, Ding D. Attacking the pandemic of physical inactivity: what is holding us back? Br J Sports Med jul;54:(13), epub 2019 nov 8

2. Eckel RH et al. 2013 AHA/ACC guideline on lifestyle management to reduce cardiovasculair risk: a report of the American College of Cardiology/American Heart Association Task Force on practice guidelines. J Am Coll Cardiol. 2014 jul 1;63 (25 Pt B), epub 2013 nov 12 